\title{
GMR
}

\section{Variability among Capsicum baccatum accessions from Goiás, Brazil, assessed by morphological traits and molecular markers}

\author{
A.L.A. Martinez ${ }^{1,2}$, J.S.P. Araújo ${ }^{3}$, C.F. Ragassi ${ }^{4}$, G.S.C. Buso ${ }^{5}$ and \\ F.J.B. Reifschneider ${ }^{4,6}$ \\ ${ }^{1}$ Instituto Federal Goiano, Campus Ceres, Ceres, GO, Brasil \\ ${ }^{2}$ Programa de Pós-Graduação em Fitotecnia, \\ Universidade Federal Rural do Rio de Janeiro, Seropédica, RJ, Brasil \\ ${ }^{3}$ Departamento de Fitotecnia, Universidade Federal Rural do Rio de Janeiro, \\ Seropédica, Rio de Janeiro, Brasil \\ ${ }^{4}$ Embrapa Hortaliças, Brasília, DF, Brasil \\ ${ }^{5}$ Embrapa Recursos Genéticos e Biotecnologia, Brasília, DF, Brasil \\ ${ }^{6}$ Embrapa Secretaria de Relações Internacinais, Brasília, DF, Brasil \\ Corresponding author: A.L.A. Martinez \\ E-mail: aurelio.martinez@ifgoiano.edu.br
}

Genet. Mol. Res. 16 (3): gmr16039074

Received August 12, 2016

Accepted December 12, 2016

Published July 6, 2017

DOI http://dx.doi.org/10.4238/gmr16039074

Copyright (C) 2017 The Authors. This is an open-access article distributed under the terms of the Creative Commons Attribution ShareAlike (CC BY-SA) 4.0 License.

\begin{abstract}
Capsicum peppers are native to the Americas, with Brazil being a significant diversity center. Capsicum baccatum accessions at Instituto Federal (IF) Goiano represent a portion of the species genetic resources from central Brazil. We aimed to characterize a C. baccatum working collection comprising 27 accessions and 3 commercial cultivars using morphological traits and molecular markers to describe its genetic and morphological variability and verify the occurrence of duplicates. This set included 1 C. baccatum var. praetermissum and 29 C. baccatum var. pendulum with potential for use in breeding programs. Twenty-two morphological descriptors, 57 inter-simple sequence
\end{abstract}


repeat, and 34 random amplified polymorphic DNA markers were used. Genetic distance was calculated through the Jaccard similarity index and genetic variability through cluster analysis using the unweighted pair group method with arithmetic mean, resulting in dendrograms for both morphological analysis and molecular analysis. Genetic variability was found among C. baccatum var. pendulum accessions, and the distinction between the two C. baccatum varieties was evident in both the morphological and molecular analyses. The 29 C. baccatum var. pendulum genotypes clustered in four groups according to fruit type in the morphological analysis. They formed seven groups in the molecular analysis, without a clear correspondence with morphology. No duplicates were found. The results describe the genetic and morphological variability, provide a detailed characterization of genotypes, and discard the possibility of duplicates within the IF Goiano C. baccatum L. collection. This study will foment the use of this germplasm collection in C. baccatum breeding programs.

Key words: Pepper; Genetic resources; Biodiversity; ISSR; RAPD; UPGMA

\section{INTRODUCTION}

Brazil is a secondary diversity center for the genus Capsicum (Sudré et al., 2010), which consists of approximately 35 taxa (species and their botanical varieties) classified according to their degree of domestication as wild, domesticated, and semi-domesticated. Among the domesticated species, C. annuиm L. var. annuиm, C. baccatum L. var. pendulum (Wild.) Eshbaugh, C. chinense Jacq., C. frutescens L., and C. pubescens Ruiz \& Pavon, only the latter is not found in Brazil (Carvalho and Bianchetti, 2008).

A Capsicum breeding program was launched in Brazil approximately 40 years ago, leading to the development of a reference germplasm bank at the Empresa Brasileira de Pesquisa Agropecuária - Embrapa (Brazilian Agricultural Research Corporation) that includes more than 4000 accessions. One of the foundations of that program was the establishment of research and professional training partnerships with other institutions in Brazil and abroad (Reifschneider et al., 2016). One such a partnership was established with the Instituto Federal Goiano - IF Goiano (Federal Institute of Goiás, Brazil) in 2009.

Embrapa's Capsicum collection includes few genotypes representing the middlenorthern area of the state of Goiás (Onoyama et al., 2011). For that reason, together with Embrapa Vegetables, the IF Goiano collected and characterized Capsicum peppers from the region, resulting in a germplasm bank with 315 accessions from 49 municipalities in the states of Goiás, Tocantins, and Mato Grosso. The genotypes were characterized and identified per species as follows: $4.1 \%$ C. annuum L., $14.4 \%$ C. baccatum L., $50 \%$ C. chinense Jacq., $14.2 \%$ C. frutescens L., and 17.2\% Capsicum sp. (Onoyama et al. 2011).

Species C. baccatum L. differs from all other Capsicum species by presenting diffuse yellowish or greenish spots on the base of each corolla lobe (Carvalho and Bianchetti, 2008). This species is subdivided into four botanical varieties: pendulum (Wild.) Eshbaugh, baccatum, praetermissum (Heiser and P.G. Sm.) Hunz., and umbilicatum (Vell.) Hunz. and Barboza (Albrecht et al., 2012).

Genetics and Molecular Research 16 (3): gmr16039074 
The pendulum variety is represented by the morphological types "dedo-de-moça" (girl's finger), which is very popular in the Brazilian cuisine, and "cambuci", although some $C$. chinense plants presenting similar fruits are also popularly named "dedo-de-moça" (Fonseca et al., 2008; Costa et al., 2016). "Dedo-de-moça" peppers have elongated fruits measuring 70 to $75 \mathrm{~mm}$ in length and 10 to $20 \mathrm{~mm}$ in diameter; their delicate shape resembles a female's finger, from which its common name arises. "Cambuci" peppers are found in northeastern South America, including Colombia, Ecuador, Peru, Bolivia, and southern and southeastern Brazil. They have the shape of a bell or a jar; thus, they are also known as "chapéu-de-bispo" or "chapéu-de-frade" (bishop's hat or friar's hat), and are not pungent.

The semi-domesticated variety baccatum, known as "cumari-verdadeira" (true-“cumari") or "pimenta-de-passarinho" (little-bird-pepper), has strongly pungent, small, oval fruits that measure approximately 10 millimeters in length and 8 millimeters in diameter. This variety is found in central Peru, Bolivia, northern Argentina, and southern and southeastern Brazil. The semi-domesticated variety praetermissum, also called "cumari-verdadeira", is only found in Brazil, mainly in its center-west and southeastern regions (Carvalho and Bianchetti, 2008).

Finally, C. baccatum var. umbilicatum consists of a group of herbaceous cultivars derived from an unknown wild progenitor, and the fruit has peculiar shapes (Albrecht et al., 2012).

Knowledge of variability and relationships among accessions is necessary for efficient management of germplasm collections (Albrecht et al., 2012). Such knowledge is achieved by means of characterization, and it provides the basis for plant breeding (Moura et al., 2013). Morphological characterization allows the description, identification, and differentiation of accessions of the same species and provides estimates of the germplasm collection variability (Carvalho et al., 2014). In the case of genus Capsicum, some preset descriptors are used (IPGRI, 1995), in addition to other descriptors that each individual researcher might consider relevant for characterizing accessions. Molecular characterization reveals polymorphisms in the DNA sequence among different individuals, thus allowing researchers to estimate their genetic diversity, identify clones and hybrids, calculate the crossing rate and kinship, construct genetic maps, and detect duplicates, thus reducing the cost and work of conservation (Rodrigues et al., 1999).

Characterization based on ISSR (inter-simple sequence repeat) markers has low cost and high reproducibility and yields a high number of polymorphic fragments. ISSR markers are dominant, and the product of amplification is unknown; i.e., they are random markers, just like RAPD (random amplified polymorphic DNA) markers. However, by having a larger primer anchor surface, ISSR markers exhibit higher reproducibility, resulting in greater specificity (Bornet and Branchard, 2001).

This study aimed to characterize an IF Goiano C. baccatum L. working collection comprising 27 accessions and 3 commercial cultivars using morphological traits and molecular markers in order to describe their genetic and morphological variability and to verify the occurrence of duplicates. The study was carried out in order to provide grounds for future use of that germplasm in plant breeding programs.

\section{MATERIAL AND METHODS}

\section{Genetic material}

A total of 27 C. baccatum genotypes from the IF Goiano Capsicum Germplasm Active

Genetics and Molecular Research 16 (3): gmr16039074 
Bank were used (Table 1). For the present study, one or two plants of each accession were selfpollinated, thus producing the seeds of the analyzed plants. Three C. baccatum var. pendulum commercial genotypes were used as controls: 'BRS Mari', 'Dedo-de-moça' (Topseed), and 'Cambuci' (Feltrin).

Table 1. Characteristics of Capsicum baccatum L. accessions preserved in a collection of the Instituto Federal Goiano (Federal Institute of Goiás, Brazil).

\begin{tabular}{|c|c|c|c|c|c|}
\hline Accession & Botanical variety & Type & Fruit shape & Fruit color at the mature stage ${ }^{1}$ & Pungency $^{2}$ \\
\hline IFET 19 & Pendulum & $\mathrm{ND}^{3}$ & Triangular & $\mathrm{DR}$ & 1 \\
\hline IFET 64 & Pendulum & Dedo-de-moça & Elongated & $\mathrm{DR}$ & 1 \\
\hline IFET 68 & Pendulum & Dedo-de-moça & Elongated & $\mathrm{R}$ & 1 \\
\hline IFET 85 & Pendulum & Dedo-de-moça & Elongated & $\mathrm{R}$ & 1 \\
\hline IFET 103 & Pendulum & ND & Triangular & LR & 1 \\
\hline IFET 110 & Pendulum & Dedo-de-moça & Elongated & $\mathrm{R}$ & 1 \\
\hline IFET 111 & Pendulum & Dedo-de-moça & Elongated & $\mathrm{R}$ & 1 \\
\hline IFET 115 & Pendulum & Dedo-de-moça & Elongated & $\mathrm{DR}$ & 1 \\
\hline IFET 120 & Pendulum & Dedo-de-moça & Elongated & $\mathrm{DR}$ & 1 \\
\hline IFET 121 & Pendulum & ND & Triangular & $\mathrm{DR}$ & 3 \\
\hline IFET 124 & Pendulum & Dedo-de-moça & Elongated & $\mathrm{R}$ & $\mathrm{Nd}$ \\
\hline IFET 137 & Pendulum & Dedo-de-moça & Elongated & $\mathrm{O}$ & 1 \\
\hline IFET 145 & Praetermissum & Cumari & Round & DR & 1 \\
\hline IFET 186 & Pendulum & Dedo-de-moça & Elongated & DR & 1 \\
\hline IFET 202 & Pendulum & Dedo-de-moça & Elongated & $\mathrm{DR}$ & 2 \\
\hline IFET 207 & Pendulum & Dedo-de-moça & Elongated & DR & 3 \\
\hline IFET 210 & Pendulum & ND & Triangular & $\mathrm{R}$ & 1 \\
\hline IFET 224 & Pendulum & Chifre-de-veado & Elongated & LR & 3 \\
\hline IFET 235 & Pendulum & Dedo-de-moça & Elongated & DR & 1 \\
\hline IFET 241 & Pendulum & ND & Triangular & $\mathrm{R}$ & 2 \\
\hline IFET 245 & Pendulum & Dedo-de-moça & Elongated & $\mathrm{DR}$ & 3 \\
\hline IFET 252 & Pendulum & ND & Elongated & $\mathrm{R}$ & 1 \\
\hline IFET 265 & Pendulum & ND & Triangular & $\mathrm{R}$ & 2 \\
\hline IFET 273 & Pendulum & ND & Triangular & $\mathrm{R}$ & 1 \\
\hline IFET 289 & Pendulum & Dedo-de-moça & Elongated & $\mathrm{DR}$ & 1 \\
\hline IFET 291 & Pendulum & ND & Triangular & $\mathrm{R}$ & 1 \\
\hline IFET 292 & Pendulum & Cambuci & bell-like & $\mathrm{R}$ & 4 \\
\hline BRS Mari & Pendulum & Dedo-de-moça & Elongated & $\mathrm{R}$ & 1 \\
\hline Cambuci & Pendulum & Cambuci & bell-like & LR & 4 \\
\hline Dedo-de-moça & Pendulum & Dedo-de-moça & Elongated & $\mathrm{R}$ & 1 \\
\hline
\end{tabular}

${ }^{1}$ Fruit color at the mature stage: DR, dark red; R, red; LR, light red; O, orange. ${ }^{2}$ Score 1 : high pungency, score 2 : medium pungency, score 3: low pungency, score 4: no pungency. ${ }^{3} \mathrm{ND}$ : undefined.

Genetics and Molecular Research 16 (3): gmr16039074 
For morphological characterization, 15 plants of each of the 30 genotypes were grown in the field using an augmented block design with 1 x $0.8 \mathrm{~m}$ spacing. For DNA extraction (molecular analysis), sowing was carried out in $300 \mathrm{~mL}$ disposable cups, and the DNA was extracted from one single plant. In addition to the 30 genotypes mentioned above, DNA from Embrapa accessions CNPH 3773 (C. chinense) and CNPH 4266 (C. frutescens) was also used in the molecular analysis. Those accessions, from different species, were selected as intentional outgroups to evidence the clustering of $C$. baccatum accessions and to act as references for the other two species.

\section{Morphological characterization}

Morphological characterization was carried out using 22 recommended descriptors for Capsicum (IPGRI, 1995). The descriptors used were number of flowers per axil, flower position, corolla color, corolla spot color, stigma exsertion, fruit color at mature stage, fruit shape, fruit length, fruit width, fruit wall thickness, fruit shape at pedicel attachment, fruit shape at blossom end, fruit blossom end appendage, fruit cross-sectional corrugation, number of locules, ripe fruit pedicel persistence, plant growth habit, and presence of calyx annular constriction, in addition to fruit position (hanging, upright, or intermediate), aroma (low, medium, or high) and pungency (high, medium, low, no, or undefined pungency).

The quantitative characteristics were transformed into binary data and analyzed qualitatively. Fruit length and fruit width were categorized into six classes; fruit wall thickness and the average weight of 10 fruits were categorized into four classes (Table 2).

Table 2. Class intervals of quantitative morphological characteristics evaluated in Capsicum baccatum peppers.

\begin{tabular}{|c|c|c|c|c|c|c|}
\hline \multirow[t]{2}{*}{ Morphological characteristic } & \multicolumn{6}{|c|}{ Class interval } \\
\hline & Class 1 & Class 2 & Class 3 & Class 4 & Class 5 & Class 6 \\
\hline Pungency (score) & 1 & 2 & 3 & 4 & & \\
\hline Fruit length $(\mathrm{mm})$ & {$[0 ; 20]$} & {$[20 ; 40]$} & {$[40 ; 60]$} & {$[60 ; 80]$} & {$[80 ; 100]$} & $>100$ \\
\hline Fruit width $(\mathrm{mm})$ & {$[0 ; 8]$} & {$[8 ; 16]$} & {$[16 ; 24]$} & {$[24 ; 32]$} & {$[32 ; 40]$} & $>40$ \\
\hline Fruit wall thickness (mm) & {$[0,0 ; 1,0]$} & {$[1,0 ; 1,5]$} & {$[1,5 ; 2,0]$} & $>2,0$ & & \\
\hline Average weight of 10 fruits $(\mathrm{g})$ & {$[0 ; 4]$} & {$[4 ; 8]$} & {$[8 ; 12]$} & $>12$ & & \\
\hline
\end{tabular}

\section{Genomic DNA extraction}

DNA was extracted from a leaf sample measuring approximately $1 \mathrm{~cm}$, collected from one single plant using the $2 \%$ cetyltrimethylammonium bromide (CTAB) protocol. Following extraction, the DNA samples were diluted based on visualization on 1\% agarose gel with a lambda standard to a working concentration of $3 \mathrm{ng}^{\mathrm{l}^{-1}}$.

\section{Amplification reactions with ISSR and RAPD primers}

For molecular characterization, the following ISSR primers were tested: i3 $\mathrm{Zm}$, i4 Zm, i5 Zm, i6 Zm, i7 Zm, i9 Zm, i10 Zm, i11 Zm, i12 Zm, i15 Zm, i16 Zm, i17 Zm, i18 Zm, i19 Zm, i21 Zm, i23 Zm, i25 Zm, i26 Zm, i27 Zm, i29 Zm, i30 Zm, i31 Zm, i32 Zm, i35 Zm, i36Zm, i38 Zm, i39 Zm, i42 Zm, i52 Zm, i53 Zm, i54 Zm, i55 Zm, i56 Zm, i57 Zm, i58 Zm, 159 Zm, i60 Zm (Gianfilippi, 2006), i1 Pv, i3 Pv, i4 Pv, i6 Pv, i7 Ps, i8 Ps, i9 Ps, i10 Ps, i11 Ps,

Genetics and Molecular Research 16 (3): gmr16039074 
and i12 Ps (Acampora et al., 2007). The following RAPD primers were also tested (Operon Technologies, USA): OPA-1, OPA-11, OPA-18, OPAB-08, OPAB-9, OPAB-11, APAB-15, OPAB-16, OPAB-17 OPF-13, OPG-4, OPG-19, OPN-7, OPO-4, OPO-7, OPO-11, OPO-18, OPR-1, OPR-10, OPR-14, POT-4, OPT-5, and OPV-14.

Amplification of DNA fragments using ISSR primers was carried out in a total reaction volume of $13 \mu$ l containing $2.59 \mu$ l Milli-Q water, $10 \%(\mathrm{v} / \mathrm{v})$ reaction buffer $(10 \mathrm{mM}$ Tris$\left.\mathrm{HCl} \mathrm{pH} 8.3,50 \mathrm{mM} \mathrm{KCl}, 1.5 \mathrm{mM} \mathrm{MgCl}_{2}\right), 0.25 \mathrm{mM}$ each dNTP, $1.3 \mu 12.5 \mathrm{mg} \mathrm{mL}^{-1}$ bovine serum albumin, $1.3 \mathrm{U}$ Taq-DNA polymerase, $0.25 \mu 150 \mathrm{mM} \mathrm{MgCl}_{2}, 0.3 \mathrm{mM}$ primer, and 9 ng template DNA. Amplification was carried out using a thermal cycler with the following program: $5 \mathrm{~min}$ at $94^{\circ} \mathrm{C}, 35$ cycles of $1 \mathrm{~min}$ at $94^{\circ} \mathrm{C}, 1 \mathrm{~min}$ at $56^{\circ} \mathrm{C}, 1 \mathrm{~min}$ at $72^{\circ} \mathrm{C}$, and $10 \mathrm{~min}$ at $72^{\circ} \mathrm{C}$ for the final elongation.

Amplification of DNA fragments using RAPD primers was carried out in a total reaction volume of $13 \mu \mathrm{L}$ containing $4.67 \mu \mathrm{L}$ Milli-Q water, $10 \%(\mathrm{v} / \mathrm{v})$ reaction buffer $(10$ $\mathrm{mM}$ Tris- $\mathrm{HCl} \mathrm{pH} 8.3,50 \mathrm{mM} \mathrm{KCl}, 1.5 \mathrm{mM} \mathrm{MgCl} 2$ ), $0.2 \mathrm{mM}$ of each dNTP, $1.04 \mu \mathrm{L} 2.5 \mathrm{mg} /$ $\mathrm{mL}$ bovine serum albumin, $1 \mathrm{U}$ Taq-DNA polymerase, $0.25 \mu \mathrm{L} 50 \mathrm{mM} \mathrm{MgCl}, 0.14 \mathrm{mM}$ primer, and 9 ng template DNA. Amplification was carried out using a thermal cycler with the following program: $92^{\circ} \mathrm{C}$ for $5 \mathrm{~min}, 40$ cycles of $1 \mathrm{~min}$ at $92^{\circ} \mathrm{C}, 1 \mathrm{~min}$ at $35^{\circ} \mathrm{C}, 2 \mathrm{~min}$ at $72^{\circ} \mathrm{C}$, and $10 \mathrm{~min}$ at $72^{\circ} \mathrm{C}$ for the final elongation.

The polymerase chain reaction (PCR) products were separated by means of horizontal electrophoresis at $160 \mathrm{~V}$ for $90 \mathrm{~min}$ on $1.5 \%$ agarose gels containing ethidium bromide $(0.2$ $\mathrm{mg} / \mathrm{mL}$ ). The gels were documented with an image capture device under ultraviolet light.

\section{Diversity analysis}

Regarding the quantitative morphological characteristics, each class (Table 2) was considered an independent trait for conversion into binary data. As an example, pungency (scores 1 to 4 ) turned into four categories (genotypes with score 1, genotypes with score 2, genotypes with score 3, and genotypes with score 4). Each genotype received a 1 for presence or 0 for absence in each category. For molecular characterization, each polymorphic amplicon was considered an independent characteristic. The presence of a given amplicon was attributed as 1 and its absence as 0 . A matrix of genetic similarity among genotypes was calculated from the binary spreadsheet using the Jaccard similarity coefficient. The genotypes were clustered according to their similarity by the Unweighted Pair Group Method with Arithmetic Mean (UPGMA) with NTSYS software, version 2.1 (Rohlf, 2000).

\section{RESULTS}

\section{Similarity based on morphological descriptors}

The similarity index among accessions varied from 18 to $100 \%$ (Figure 1), based on morphological descriptors. Four groups were visually established in the plot, with a cutoff point at 35\% similarity. Clustering reflected differences among the main C. baccatum L. morphological types known ("dedo-de-moça", "cambuci" and "cumari"). Three groups (I, II, and III) from the four groups established were exclusively composed of C. baccatum var. pendulum. Genotypes with round- or triangular-shaped fruits were included in group I. Group II predominantly consisted of genotypes with elongated fruits, except for accession IFET 210.

Genetics and Molecular Research 16 (3): gmr16039074 
Morphological type "cambuci” (accession IFET 292 and the commercial cultivar 'Cambuci') formed the third group. Accession IFET 145, the only C. baccatum var. praetermissum, formed the fourth and most dissimilar group in the morphological analysis.

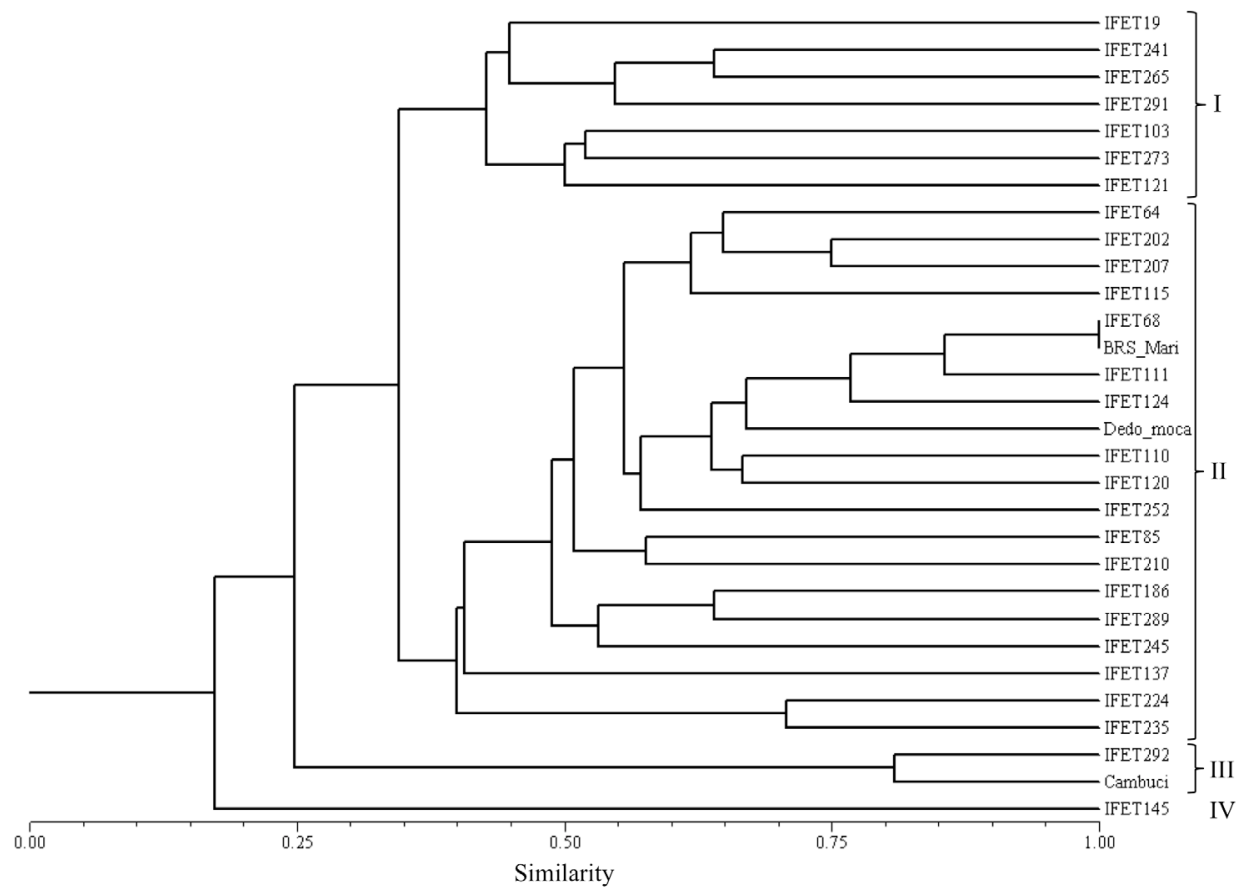

Figure 1. Cluster analysis of 30 genotypes of Capsicum baccatum L., carried out through the UPGMA method based on 22 morphological descriptors.

Formation of clusters based on morphological types was expected, as the commonly known Capsicum baccatum L. morphological types were empirically established based on fruit characteristics. Fruit descriptors represented $73 \%$ of the total morphological descriptors used for building the dendrogram in the present study.

Variability among genotypes was also detected within the four clusters. Group II was predominantly composed of the morphological type "dedo-de-moça", but accessions of morphological types other than commercial "dedo-de-moça" were also clustered in Group II, including IFET 210, which has triangular-shaped fruits; IFET 224, a long red pepper of the morphological type commonly known as "chifre-de-veado" (antler); and IFET 252, which has elongated upright fruits and is similar to the Malagueta chili pepper (C. frutescens) but longer and wider. The morphological descriptors used could not distinguish IFET 68 and 'BRS Mari'. 'BRS Mari' is a commercial "dedo-de-moça" cultivar launched in 2009, selected from a population harvested in Brasilia, Distrito Federal, Brazil. It was introduced to the Embrapa Vegetables Capsicum germplasm bank in 1980. Accession IFET 68 was collected in 2009 in Itaguari, Goiás State, Brazil, from an unknown source origin.

The two genotypes in group III, corresponding to the morphological type "cambuci", differed as to stigma exsertion (exserted stigma in IFET 292 and at the same level as the 
anthers in commercial 'Cambuci') and fruit color at the mature stage (the mature fruit had a darker red color in IFET 292 compared to commercial 'Cambuci').

\section{Similarity based on molecular markers}

From the 47 tested ISSR primers, $10(21.3 \%)$ amplified 57 polymorphic amplicons in PCR. From the 24 tested RAPD primers, 7 (29.2\%) yielded 34 polymorphic amplicons (Table 3 ).

\begin{tabular}{|c|c|c|}
\hline \multirow[t]{2}{*}{ Primer } & Sequence $\left(5^{\prime}-3^{\prime}\right)$ & Size of polymorphic amplicons (base pairs) \\
\hline & ISSR & \\
\hline i5 $\mathrm{Zm}$ & CACACACACACACACAGC & $800 ; 830 ; 850 ; 1300 ; 200$ \\
\hline i12 Zm & GGTCAACACACACACAC & $1000 ; 1600 ; 1650$ \\
\hline i1 $18 \mathrm{Zm}$ & GTGCTCTCTCTCTCTCTC & $600 ; 700 ; 850 ; 900 ; 950 ; 1000 ; 1200 ; 1450 ; 1600 ; 1630 ; 1700 ; 1950 ; 2050$ \\
\hline $\mathrm{i} 29 \mathrm{Zm}$ & GTGTGTGTGTGTC & $400 ; 500 ; 580 ; 600 ; 700 ; 750 ; 870$ \\
\hline $\mathrm{i} 32 \mathrm{Zm}$ & AGCAGCAGCAGC & $780 ; 800 ; 850 ; 880 ; 985 ; 1000 ; 1050 ; 1070 ; 1400 ; 1600 ; 1650 ; 1750$ \\
\hline $\mathrm{i} 38 \mathrm{Zm}$ & AGCAGCAGCAGCAT & $400 ; 470 ; 500 ; 650 ; 850$ \\
\hline $\mathrm{i} 39 \mathrm{Zm}$ & AGCAGCAGCAGCAC & 640 \\
\hline i1 $\mathrm{Pv}$ & GACAGACAGACARG & $280 ; 320 ; 670 ; 750 ; 840$ \\
\hline i4 Pv & YRGACAGACAGACA & $320 ; 400$ \\
\hline \multirow[t]{3}{*}{ i7 Ps } & AGAGAGAGAGAGAGAGYG & $350 ; 400 ; 450 ; 500$ \\
\hline & Total number of polymorphic amplicons & 57 \\
\hline & RAPD & \\
\hline OPF-13 & GGCTGCAGAA & $750 ; 800 ; 850$ \\
\hline OPN-7 & CAGCCCAGAG & $520 ; 800 ; 900 ; 1200 ; 1300$ \\
\hline OPO-7 & CAGCACTGAC & $250 ; 300 ; 450 ; 520 ; 600 ; 850$ \\
\hline OPR-1 & TGCGGGTCCT & $370 ; 600 ; 750 ; 800 ; 1000 ; 1100 ; 1600$ \\
\hline OPR-10 & CCATTCCCCA & $500 ; 600 ; 950 ; 1000$ \\
\hline OPR-14 & CAGGATTCCC & $300 ; 400 ; 530 ; 800 ; 850$ \\
\hline \multirow[t]{2}{*}{ OPT-5 } & GGGTTTGGCA & $480 ; 600 ; 800 ; 1500$ \\
\hline & Total number of polymorphic amplicons & 34 \\
\hline
\end{tabular}

Among the ISSR primers, i18 Zm, i29 Zm, and i32 Zm yielded the highest numbers of polymorphic amplicons; namely, $56 \%$ of the total yielded by this type of marker (Figure 2).

Genetic similarity among genotypes varied from 15 to $93 \%$. The dendrogram resulting from 57 ISSR and 34 RAPD markers allowed for the formation of four groups with a cutoff value between 35 and 65\% similarity (Figure 3). Groups III and IV corresponded to the genotypes included in the analysis as references for other Capsicum species; namely, $C$.

Genetics and Molecular Research 16 (3): gmr16039074 
chinense and $C$. frutescens. Group II consisted of the single representative of $C$. baccatum var. praetermissum (IFET 145). The remainder of the genotypes, all corresponding to C. baccatum var. pendulum, formed group I.

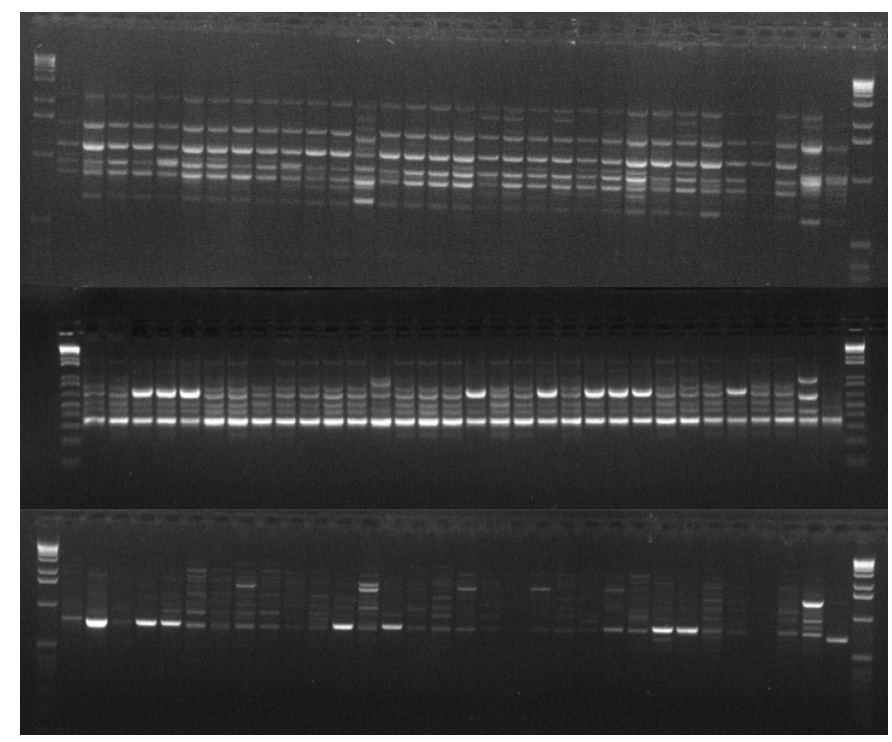

Figure 2. Agarose 1\% gel with primers ISSR i18 Zm, i29 Zm, and i32 Zm, and a 1-kb DNA ladder. From left to right, accessions IFET 19, 64, 68, 85, 103, 110, 111, 115, 120, 121, 124, 137, 145, 186, 202, 207, 210, 224, 235, 241, 245, 252, 265, 273, 289, 291, 292, 'BRS Mari', commercial 'Cambuci', commercial 'Dedo-de-moça', CNPH 4266 (Capsicum frutescens), and CNPH 3773 (Capsicum chinense).

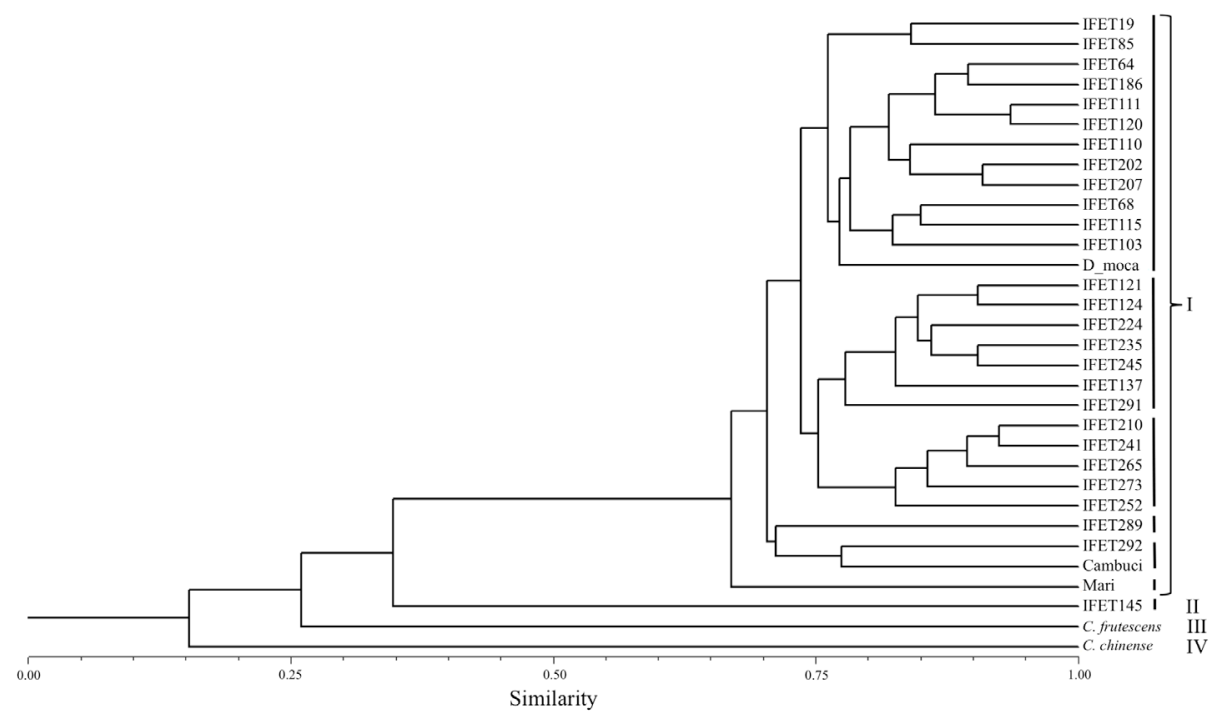

Figure 3. Cluster analysis of Capsicum genotypes carried out through the UPGMA clustering method based on 57 ISSR and 34 RAPD polymorphic amplicons.

Genetics and Molecular Research 16 (3): gmr16039074 
Similarity among the genotypes included in group I was over $65 \%$, with no correspondence being found relative to the different $C$. baccatum var. pendulum morphological types. Because of the large concentration of genotypes in this group, its subgroups were analyzed in further detail based on a higher cutoff point of $75 \%$ similarity.

The second cutoff point ( $75 \%$ similarity) subdivided Group I into six groups. The cultivar BRS Mari did not cluster with any of the other accessions, including IFET 68, a morphologically similar genotype (Figure 1). Just as in the case of morphological analysis, IFET 292 (morphological type "cambuci") clustered with the commercial genotype 'Cambuci'. Accession IFET 289, a "dedo-de-moça" pepper, was relatively close to, although not clustered with, the "cambuci" genotypes, while somewhat distant from the remaining "dedo-de-moça" accessions. The remainder of the subgroups, consisting of different types of peppers, evidenced the genetic variability among C. baccatum var. pendulum accessions of the IF Goiano Capsicum Germplasm Active Bank and highlighted the potential for heterosis generation in directed crossings.

The subgroup with accessions IFET 210 and IFET 252 as endpoints was characterized by triangular-shaped fruits, except for IFET 252, whose fruit is elongated. Genotypes IFET 210 and IFET 241 exhibited high similarity, differing only in three bands yielded by the 132 $\mathrm{Zm}$ primer, with $800 \mathrm{bp}$ and $1650 \mathrm{bp}$ present in IFET 210 and a $1750 \mathrm{bp}$ DNA segment present in IFET 241.

The subgroup ranging from IFET 121 to IFET 291 included genotypes of the "dedo-de-moça" morphological type, one plant with triangular-shaped fruit (IFET 291), and one plant with fruit corresponding to the "chifre-de-veado" morphological type (IFET 224). Accessions IFET 121 and IFET 124 exhibited high similarity, only differing by one amplicon in each primer: i12 Zm (1650 bp in IFET 124), i18 Zm (850 bp in IFET 124), i7 Ps (400 bp in IFET 121), and OPO-7 (450 bp in IFET 124). Nevertheless, IFET 121 exhibited variability relative to the fruit shape (elongated and triangular, Figure 4), possibly due to genetic segregation. Although the analyzed genotypes were obtained by self-pollination (generation 1), the seeds in the accessions comprising the germplasm bank are the result of uncontrolled crossing. Thus, they might be the product of cross-fertilization. Despite the predominance of self-pollination in genus Capsicum, rates of cross-fertilization ranging from $2 \%$ to $90 \%$ in field conditions were found (Pickersgill, 1997), depending on the environmental conditions and the physical distance among plants. In addition to the natural crossings within the same species, gene flow might occur among species (Monteiro et al., 2011; Martins et al., 2015), a phenomenon that has been used to transfer resistance genes, such as genes for Tobacco Mosaic Virus resistance, from C. chinense and C. chacoense to C. annuum (Pickersgill, 1997). Also regarding this subgroup, accessions IFET 235 and IFET 245 exhibited high similarity, differing only in one amplicon for each primer: $118 \mathrm{Zm} \mathrm{(850}$ bp in IFET 235), i7 Ps (450 bp in IFET 245), OPO-7 (450 bp in IFET 235), and OPF-13 (800 bp in IFET 235).

The subgroup ranging between IFET 64 and the commercial "Dedo-de-moça" consisted of genotypes corresponding to the "dedo-de-moça" morphological type, except for IFET 103, which had round-shaped fruits. Within this subgroup, IFET 111 and IFET 120 differed in three amplicons, one yielded by the i29 Zm primer (700 bp in IFET 111) and two yielded by i7 Ps (450 bp in IFET 111 and 500 bp in IFET 120). Finally, one subgroup consisted of IFET 19 (triangular-shaped fruits) and IFET 85 (dedo-de-moça).

Genetics and Molecular Research 16 (3): gmr16039074 


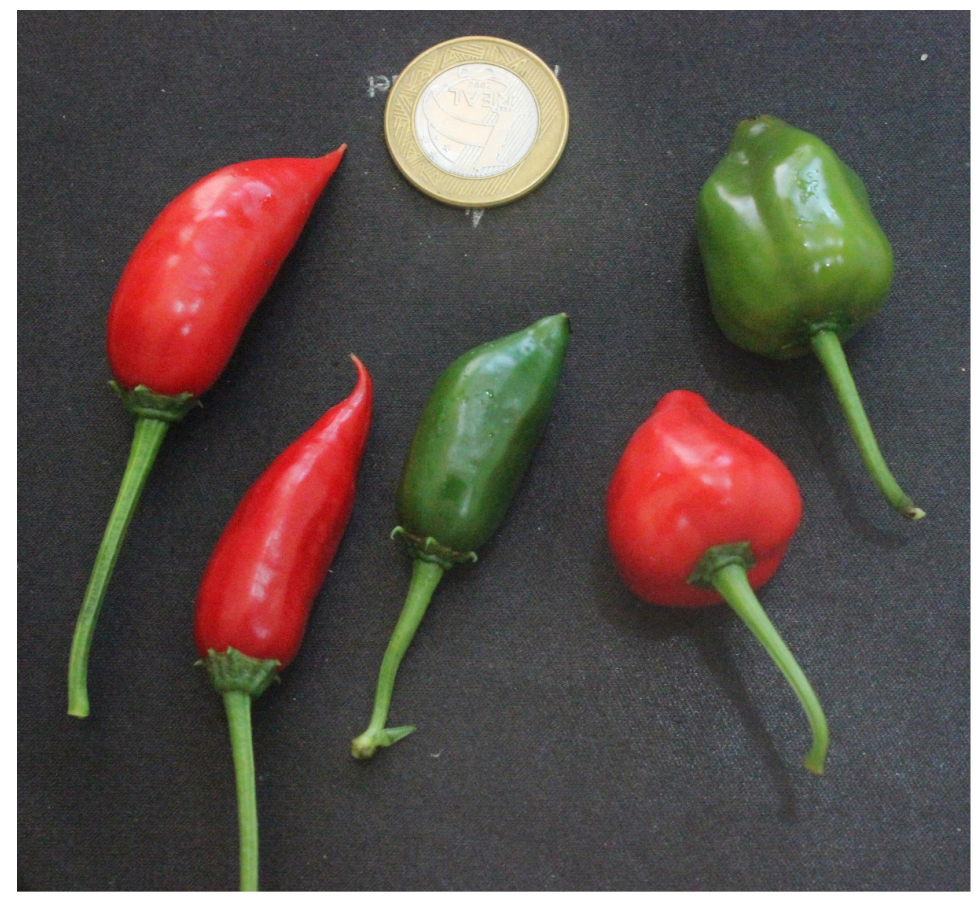

Figure 4. Fruits of accession IFET 121 (Capsicum baccatum L. var. pendulum) plants exhibiting segregation of their morphological characteristics.

\section{DISCUSSION}

Given the close relative proximity of certain Capsicum species, some studies have proposed the concept of a "species complex". Based on this concept, three complexes were defined: a) the $C$. annuиm complex (C. annuиm var. annuиm, $C$. annuиm var. glabriusculum, $C$. frutescens, $C$. chinense, and C. galapagoense), b) the $C$. pubescens complex (C.pubescens, C. eximium, and C. cardenasii), and c) the C. baccatum complex (C. baccatum var. pendulum, C. baccatum var. baccatum, C. baccatum var. praetermissum, and C. tovarii) (Ince et al., 2010; Albrecht et al., 2012). The clear difference between C. baccatum and the other two species included in the molecular cluster analysis carried out in the present study agrees with their attribution to different complexes.

The separation between $C$. baccatum var. pendulum and $C$. baccatum var. praetermissum is particularly noteworthy, because it was highly evident in both the molecular and the morphological analyses. The distinction between $C$. baccatum var. pendulum and $C$. baccatum var. praetermissum in the present study was comparable to the distinction among the three different species in the molecular analysis. In fact, the low genetic similarity between these two varieties has been previously discussed. The results of Kochieva et al. (2004), who used molecular tools, support the idea that the variety praetermissum is an autonomous species (C. praetermissum) instead of a variety within C. baccatum. This idea was previously suggested by Albrecht et al. (2012). Therefore, the high level of separation found in the present study agrees with these assertions. 
According to the morphological analysis, the variability between the commercial cultivar 'Cambuci' and the remainder of the C. baccatum var. pendulum accessions was similar to the variability between $C$. baccatum var. pendulum and $C$. baccatum var. praetermissum. Cambuci pepper, also known as "chapéu-de-bispo" or "chapéu-de-frade" (bishop's hat or friar's hat), was classified as C. baccatum var. umbilicatum by Hunziker and Barbosa based on morphological differences (Albrecht et al., 2012). However, Carvalho and Bianchetti (2008) consider it a typical morphological type of C. baccatum var. pendulum. Albrecht et al. (2012) also contested the classification of this type as a different variety from C. baccatum var. pendulum based on genetic clustering using amplified fragment length polymorphism (AFLP) markers. Similar to the study carried out by Albrecht et al. (2012), in the molecular analysis carried out in the present study, the "Cambuci" genotypes clustered with other accessions of the variety pendulum.

Molecular and morphological analysis in the present study agreed in a number of aspects, such as the separation of IFET 145 (C. baccatum var. praetermissum) from the $C$. baccatum var. pendulum genotypes and the clustering of commercial 'Cambuci' and IFET 292. Nevertheless, differences between the two methods were evident, such as the clustering of IFET 68 and 'BRS Mari' as identical genotypes in the morphological analysis, which was refuted by the molecular analysis, and the clear morphological separation of "cambuci" from the other C. baccatum var. pendulum, which was not shown in the molecular analysis. Morphological characterization prioritized flower and fruit characteristics, while molecular characterization was random due to the random positioning of ISSR and RAPD markers in the genome. The expected discrepancies between these two types of analysis reinforce the relevance of using both to achieve an effective characterization of a germplasm.

In conclusion, the results of this study described the genetic and morphological variability, provided a detailed characterization of genotypes, and eliminated the possibility of duplicates within the IF Goiano C. baccatum L. working collection. This study will foment the use of this germplasm collection in C. baccatum breeding programs.

\section{Conflicts of interest}

The authors declare no conflict of interest.

\section{ACKNOWLEDGMENTS}

The authors thank Coordenação de Aperfeiçoamento de Pessoal de Nível Superior (CAPES) for a $\mathrm{PhD}$ grant to the first author, the Graduate Program in Plant Science Universidade Federal Rural do Rio de Janeiro, Embrapa Recursos Genéticos e Biotecnologia, and Embrapa Hortaliças (Project \#02.12.02.007.00.00).

\section{REFERENCES}

\footnotetext{
Acampora A, Ciaffi M, Pace C, Paolacci AR, et al. (2007). Pattern of variation for seed size traits and molecular markers in Italian germplasm of Phaseolus coccineus L. Euphytica 157: 69-82. http://dx.doi.org/10.1007/s10681-007-9397-3 Albrecht E, Zhang D, Saftner RA and Stommel JR (2012). Genetic diversity and population structure of Capsicum baccatum genetic resources. Genet. Resour. Crop Evol. 59: 517-538. http://dx.doi.org/10.1007/s10722-011-9700-y

Bornet B and Branchard M (2001). Nonanchored Inter Simple Sequence Repeat (ISSR) markers: reproducible and specific tools for genome fingerprinting. Plant Mol. Biol. Report. 19: 209-215. http://dx.doi.org/10.1007/BF02772892
}

Genetics and Molecular Research 16 (3): gmr16039074 
Carvalho SIC and Bianchetti LB (2008). Botânica e recursos genéticos. In: Pimentas Capsicum (Ribeiro CSC, Lopes CA, Carvalho SIC, Henz GP, et al., eds.). Embrapa Hortaliças, Brasilia, 39-54.

Carvalho SIC, Ragassi CF, Bianchetti LB, Reifschneider FJB, et al. (2014). Morphological and genetic relationships between wild and domesticated forms of peppers (Capsicum frutescens L. and C. chinense Jacquin). Genet. Mol. Res. 13: 7447-7464. http://dx.doi.org/10.4238/2014.September.12.11

Costa MPSD, do Rêgo MM, da Silva AP, do Rêgo ER, et al. (2016). Characterization and genetic diversity of pepper (Capsicum spp) parents and interspecific hybrids. Genet. Mol. Res. 15: 1-12 http://dx.doi.org/10.4238/gmr.15027652.

Fonseca RM, Lopes R, Barros WS, Lopes MTG, et al. (2008). Morphologic characterization and genetic diversity of Capsicum chinense accessions along the upper Rio Negro - Amazonas. Crop Breed. Appl. Biotechnol. 8: 187-194. http://dx.doi.org/10.12702/1984-7033.v08n03a02

Gianfilippi F (2006). Studio della diversita molecolare in popolazioni locali italiane di lenticchia (Lens culinaris Medik) tramite marcatori ISSR. Thesi de láurea agrária, Università degli Studi della Tuscia, Tuscia.

Ince AG, Karaca M and Onus AN (2010). Genetic relationships within and between Capsicum species. Biochem. Genet. 48: 83-95. http://dx.doi.org/10.1007/s10528-009-9297-4

IPGRI (International Plant Genetic Resources Institute) (1995). Descriptors for Capsicum (Capsicum spp.). IPGRI, Rome.

Kochieva EZ, Ryzhova NN, van Dooijeweert W and Boukema IW (2004). Assessment of Genetic Relationships in the Genus Capsicum Using Different DNA Marker Systems. Proceedings of the XIIth EUCARPIA Meeting on Genetics and Breeding of Capsicum and Eggplant, Noordwijkerhout, 44-50.

Martins KC, Pereira TNS, Souza SAM, Rodrigues R, et al. (2015). Crossability and evaluation of incompatibility barriers in crosses between Capsicum species. Crop Breed. Appl. Biotechnol. 15: 139-145 http://dx.doi.org/10.1590/1984$70332015 \mathrm{v} 15 \mathrm{n} 3 \mathrm{a} 25$.

Monteiro CES, Pereira TNS and Campos KP (2011). Reproductive characterization of interspecific hybrids among Capsicum species. Crop Breed. Appl. Biotechnol. 11:241-249. http://dx.doi.org/10.1590/S1984-70332011000300006

Moura EF, Farias Neto JT, Sampaio JE and Ramalho GF (2013). Identification of duplicates of cassava accessions sampled on the North Region of Brazil using microsatellite markers. Acta Amazon. 43: 461-467. http://dx.doi.org/10.1590/ $\underline{\text { S0044-59672013000400008 }}$

Onoyama SS, dos Anjos UG, Reifschneider FJB, Melo WF, et al. (2011). Coletando, conservando e utilizando a biodiversidade de pimentas em goiás: agregando conhecimento e valor do bioma à agroindústria. Ateliê Geográfico 5: 106-122 10.5216/ag.v5i2.15479.

Pickersgill B (1997). Genetic resources and breeding of Capsicum spp. Euphytica 96: 129-133. http://dx.doi. org/10.1023/A:1002913228101

Reifschneider FJB, Lopes CA and Ribeiro CSC (2016). Continuity, focus and impact: a commented historical perspective on Embrapa Vegetables' extended Capsicum breeding program. Hortic. Bras. 34: 155-160. http://dx.doi.org/10.1590/ $\underline{\mathrm{S} 0102-053620160000200002}$

Rodrigues JM, Berke T, Engle L and Nienhuis J (1999). Variation among and within Capsicum species revealed by RAPD markers. Theor. Appl. Genet. 99: 147-156. http://dx.doi.org/10.1007/s001220051219

Rohlf FJ (2000). NTSYS-pc: Numerical taxonomy and multivariate analysis system (version 2.1). Exeter, New York.

Sudré CP, Gonçalves LSA, Rodrigues R, do Amaral Júnior AT, et al. (2010). Genetic variability in domesticated Capsicum spp as assessed by morphological and agronomic data in mixed statistical analysis. Genet. Mol. Res. 9: 283-294. http://dx.doi.org/10.4238/vol9-1gmr698

Genetics and Molecular Research 16 (3): gmr16039074 